
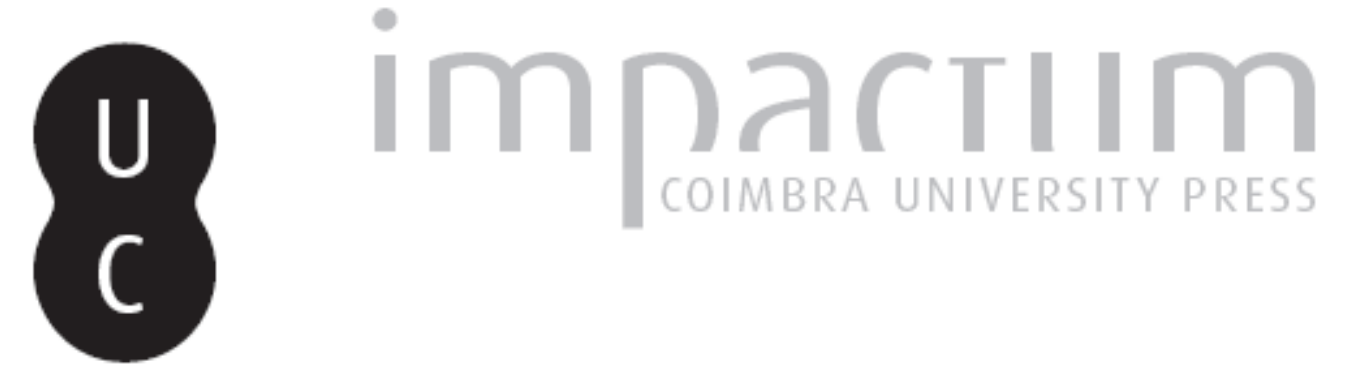

\title{
A Europa na diplomacia portuguesa: uma visão comparativa pós-guerras
}

\section{Autor(es): Baltazar, Isabel}

Publicado por: Centro de Informação Europe Direct de Aveiro; Centro de Estudos
Interdisciplinares do Século XX

URL

persistente:

URI:http://hdl.handle.net/10316.2/33982

DOI:

DOI:http://dx.doi.org/10.14195/1647-6336_11_11

Accessed : $\quad$ 26-Apr-2023 10:47:24

A navegação consulta e descarregamento dos títulos inseridos nas Bibliotecas Digitais UC Digitalis, UC Pombalina e UC Impactum, pressupõem a aceitação plena e sem reservas dos Termos e Condições de Uso destas Bibliotecas Digitais, disponíveis em https://digitalis.uc.pt/pt-pt/termos.

Conforme exposto nos referidos Termos e Condições de Uso, o descarregamento de títulos de acesso restrito requer uma licença válida de autorização devendo o utilizador aceder ao(s) documento(s) a partir de um endereço de IP da instituição detentora da supramencionada licença.

Ao utilizador é apenas permitido o descarregamento para uso pessoal, pelo que o emprego do(s) título(s) descarregado(s) para outro fim, designadamente comercial, carece de autorização do respetivo autor ou editor da obra.

Na medida em que todas as obras da UC Digitalis se encontram protegidas pelo Código do Direito de Autor e Direitos Conexos e demais legislação aplicável, toda a cópia, parcial ou total, deste documento, nos casos em que é legalmente admitida, deverá conter ou fazer-se acompanhar por este aviso.

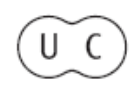


DEBATER

A EUROPA

jul-dez 2014

QUE EUROPA(S)?

CONTEXTOS E DESAFIOS 


\section{A Europa na Diplomacia portuguesa. uma visão comparativa pós-guerras}

Isabel Baltazar

Investigadora de Pós-doutoramento FCT/CEIS20-UC

Membro do Team Europe da Comissão Europeia

E-mail: ibaltazar@fcsh.unl.pt

Europa, sonho futuro!

Europa, manhã por vir, fronteiras sem cães de guarda, nações com seu riso franco abertas de par em par!

Europa sem misérias arrastando seus andrajos, virás um dia? virá o dia em que renasças purificada?

Europa, ó mundo a criar! Adolfo Casais Monteiro, Europa

\section{Resumo}

Este estudo procura olhar para a Europa numa perspectiva comparativa entre as guerras do século XX. Uma visão percepcionada a partir das fontes sobre a unidade e a construção europeia existentes no Arquivo Histórico-Diplomático do Ministério dos Negócios Estrangeiros, em Portugal. A partir desta documentação diplomática, podemos compreender a evolução da EUROPA-PROJECTO, apresentada no período entre-guerras, para uma EUROPA-REALIDADE, concretizada pela efectiva construção europeia arquitectada a partir do segundo conflito mundial. Entre a Ideia ou Ideias para a Europa, sonhadas ao longo de toda a sua História, a Europa não poderia fazer-se sem o sonho, mas não podia ficar só pelo sonho. Os projectos europeus anunciados na pósprimeira guerra culminariam no projecto de "união federal europeia" de Aristides Briand, no entanto, sem efectiva realização. O espírito dos visionários da Europa 
inspiraria os fundadores da construção europeia, que, pelo "método dos pequenos passos" tornariam o sonho realidade. Mas, a Europa

continua, ainda, a ser um "Sonho Futuro".

Palavras-Chave: Europa; Unidade Europeia; Construção Europeia; Guerras; Futuro

\begin{abstract}
This essay aims to look at Europe in a comparative perspective between the 20th century wars. A perceived vision from the sources about the unity and European construction that exist in the Historical-Diplomatic Archive of the Ministry of Foreign Affairs, in Portugal. From this diplomatic documentation, we can comprehend the evolution of the EUROPE-PROJECT, presented in the between-wars period, to a EUROPE -REALITY, achieved by the effective European construction architected from the second worldwide conflict. Among the Idea or Ideas to Europe, dreamt throughout all its History, Europe couldn't be done without the dream, but it couldn't remain only on the dream. The European projects announced in the post-first war would culminate in the project of "European federal union" of Aristides Briand, however, without effective accomplishment. The spirit of the visionaries of Europe would inspire the founders of the European construction, which, through the "method of the small steps" would make the dream become a reality. But, Europe, still remains as the "Future Dream".
\end{abstract}

Key-Words: Europe; European Unity; European Construction; Wars - Future

A ideia de Europa unida ressurgiu sempre que a Europa viveu conflitos à escala mundial, quer a seguir à primeira grande guerra, quer após a segunda, ainda mais devastadora do que a primeira. No entanto, a ideia de consciência europeia sempre existiu ao longo da história, como bem o demonstra Denis de Rougemont, quando percorre o tempo e encontra laços dessa união desde Hesíodo. ${ }^{1}$

Essa consciência fundamenta-se antes de mais, na unidade da cultura europeia, tão controversa que ela seja, e por mais plural que pareça a sua existência. Mas, na sua essencialidade, a Europa é una, e tanto mais clara se torna essa unidade, quando comparada com o resto do Mundo, aos olhos do qual ela tem uma identidade própria.

\footnotetext{
${ }^{1}$ Denis de Rougemont, Vingt-Huit siècles d' Europe.La Conscience européenne a travers les textes d' Hésiode a nos jours, Paris, Payot, 1961. Esta obra, sendo uma referência para esta temática, concilia ser uma antologia de fontes com a reflexão sobre as mesmas.
} 
Mas internamente, a Europa está longe dessa aparente unidade, e, politicamente, ainda são uma utopia os "Estados Unidos da Europa".

Este estudo tratará a evolução da ideia europeia entre guerras até à formalização do projecto de União Europeia por Aristides Briand. Procurará ir seguindo os reflexos em Portugal desse "espírito europeu", que no caso político português se traduziu num posicionamento face ao plano Briand, aquele que suscitou uma maior abordagem do ponto de vista diplomático na época, para chegar às soluções emergentes surgidas a seguir à Segunda Grande Guerra, e, verdadeiramente na génese da Construção Europeia que se seguirá e cujos efeitos prosseguiriam até à actualidade.

Este trabalho pretende, ainda, ser uma síntese de um trabalho de investigação e análise das fontes sobre a integração europeia existentes no Arquivo HistóricoDiplomático do Ministério dos Negócios Estrangeiros, em Portugal. Este arquivo constitui uma fonte privilegiada para perceber os principais passos da construção europeia no século XX. Pretende-se estudar a documentação existente desde o período entre-guerras até ao final da segunda grande guerra, para compreender a Europa a partir da visão da Diplomacia Portuguesa. Paralelamente, para além de percepcionar os esforços de construção europeia empreendidos pós-guerra, comunicados a Portugal pelas legações diplomáticas, visualiza-se, também o outro olhar - o não europeu proveniente do governo português, tomando uma posição de certa exterioridade de Portugal em relação ao processo de construção europeia. A Europa na Diplomacia Portuguesa pretende percorrer as origens de uma Europa Unida ocorridas no período entre-guerras até à efectiva construção europeia conseguida após a segunda guerra (1945-1948).

Aliás, a este propósito é muito curioso constatar que Portugal sendo Europeu, mas com um posicionamento Além-Mar, esteve sempre a par dos projectos e realizações europeias, e, apesar de "observador", não se "comprometendo" politicamente com o projecto europeu, sempre mostrou perceber as virtualidades de uma efectiva unidade europeia. 


\section{I - Portugal e a Unidade Europeia após a primeira guerra}

\section{A Pan-Europade Coudenhove-Kalergi}

Nem os tratados de paz nem as organizações internacionais, no contexto específico, a SDN, garantiam efectivamente a impossibilidade ou improbabilidade da guerra. A nova ordem europeia estava, a todo o momento, ameaçada. Os problemas não resolvidos ameaçavam uma nova desordem. Era necessário, por isso, encontrar projectos mais consistentes e aprofundados do que o simples comprometimento dos estados em cumprirem os tratados. Prova evidente disto mesmo eram as relações francoalemãs, que, a qualquer momento podiam estar em perigo, como aconteceria em 1923, quando a Alemanha não pagando as reparações de guerra, viu as tropas francesas e belgas invadirem o Ruhr. Os nacionalismos exigiam outro tipo de soluções, mais consistentes, profundas e duradouras.

Surgiam, assim, os movimentos pacifistas que revelavam o sentimento dos povos europeus em preservar a paz. Careciam, no entanto, de um pragmatismo político que lhes desse eficácia, ou de um interesse comum, por exemplo económico, que se revelasse vantajoso. Os partidários de uma Europa Unida encontravam na história comum do passado fundamentos para a continuar: as raízes comuns - a Grécia antiga, o Império Romano, o Cristianismo. Mas, agora, querem uma Nova Europa. ${ }^{2}$

Chegou o momento do cosmopolita Coudenhove-Kalerg apresentar o seu projecto. $^{3}$ Desde finais de 1922 que vinha apelando à necessidade de uma Europa Unida. Chegou a propôr a Masaryk, presidente checo, um projecto de União da Europa, ao que aquele terá respondido a ideia ser boa mas não ter chegado a hora de realizar os Estados-Unidos da Europa. Decidiu, por isso, fazê-lo através da divulgação, em diversos jornais europeus, duma mensagem onde expunha a sua ideia sobre a criação de uma União Pan-Europeia. É de salientar que a 21 de Julho de 1922 publicaria na imprensa um artigo sobre a questão europeia, simultaneamente em Viena (Neue Freie

\footnotetext{
2 Neste caso encontra-se a obra do Dinamarquês Arzt Heerfordt, A Nova Europa, que obtém então grande sucesso.

3 Coudenhove-Kalergi nasceu em Tóquio (1894), filho de pai austríaco e mãe Japonesa. Foi criado em Viena, viria a ser cidadão checo em 1919, e naturalizado francês em 1939. Durante a segunda guerra estaria exilado na América. Destacamos a acção de Coudenhove-Kalergi devido não só ao interesse da sua proposta como, também, devido ao alcance que ela viria a ter no futuro.
} 
Press) e em Berlim (Vossische Zeitung), seguindo-se outros, entre os quais, um intitulado "Pan-Europa": ein Vorschlag" (Pan-Europa: um projecto) ${ }^{4}$.

No ano seguinte essa mensagem seria completada por uma obra que intitulou Pan-Europa ${ }^{5}$, e que viria a ter grande divulgação e repercussão a diversos níveis, muito particularmente, na esfera política que a leu com grande interesse. Coudenhove-Kalergi escreveu este texto com uma intenção iminentemente pragmática, desejando que o livro despertasse um grande movimento político em todas as nações europeias. Considerou, ainda, que esse movimento estava latente nas consciências adormecidas, já que muitos anteriormente tiveram o mesmo sonho. No entanto, bem poucos se decidiram a pôr em marcha um movimento para uma Europa Unida, que, agora, urgia criar. Esta obra, parte da evidência de que embora o mundo estivesse cada vez mais próximo devido ao progresso tecnológico, nomeadamente ao avanço das comunicações, esta proximidade não tinha correspondência política ${ }^{6}$. Segundo este autor, o erro da SDN foi tentar agrupar povos e estados sem qualquer afinidade histórica, cultural, política e económica. Assim, o seu projecto era conseguir uma reorganização mais próxima da realidade, não incluindo, por isso, o Reino Unido, base de um Império extra-europeu, e a Rússia, incluída numa União Soviética de natureza asiática. A Pan-Europa designava, pois, uma "união política e económica de todos os Estados Europeus, da Polónia a Portugal, numa federação de Nações"7,

Verificando estar em marcha uma nova guerra, só pela conjugação de afinidades e seguindo o modelo dos Estados-Unidos da América era possível uma Nova Europa, em cuja base estaria, indiscutivelmente, a reconciliação franco-alemã. Na sequência das anteriores mensagens, defendia a urgência de (re) pensar a Europa, reorganizando-a de forma a que recuperasse a sua força política no mundo. Para isso, tornar-se-ia imperioso evitar a nível político o bolchevismo Russo, e a dominação económica americana. Só uma nova forma de organização política que transformasse a Velha Europa num todo poderia resultar: tratava-se efectivamente de unir os diversos poderes políticos nacionais num poder supranacional. Considerando que a causa da decadência da Europa "é política" e não "biológica", Coudenhove-Kalergi dirigia-se, por isso, directamente aos

\footnotetext{
${ }^{4}$ Para uma completa listagem destes artigos deve ler-se: Fondation Archives Européennes, Pan- Europe et le mouvement paneuropéenne. Guide de recherche, Genève, 1994.

5 Esta obra seria rapidamente traduzida em quinze línguas. Neste texto será utilizada a tradução francesa mais recente: Coudenhove-Kalergi, Pan-Europe, Paris, PUF, 1988.

6 Coudenhove-Kalergi, op. cit., p. 18-19.

${ }^{7}$ Ibidem, p. 26.
} 
políticos $^{8}$ a quem pedia "transferências" de soberania. Inspirando-se, claramente, no modelo federal dos Estados-Unidos da América, propunha uma união política europeia, capaz de unir parlamentos nacionais e povos europeus. Aos últimos dirigia, também, um apelo de união, exortando-os a desejarem a constituição de uma União Pan-Europeia, cuja expressão política fosse, também, expressão de um verdadeiro sentimento de solidariedade dos seus povos. Queria, assim, captar a simpatia da opinião pública para tomar como sua a causa da unificação europeia.

Após o sucesso da obra citada ${ }^{9}$, seria a vez de fundar, em 1924, a União PanEuropeia, primeiro movimento federalista na Europa, cujo orgão de divulgação seria a revista mensal Pan-Europa Seriam, então, criados os comités nacionais deste movimento pan-europeu, salientando-se o de Áustria sob a direcção de Seipel, no Luxemburgo liderada por Mayrisch, em França com a adesão de Loucheur, Herriot e Briand na Checoslováquia com Bénès, e na Alemanha contando com o apoio de Lobe, Adenauer e Einstein. O movimento pan-europeu durante os anos seguintes iria ter uma forte presença na vida europeia ${ }^{10}$. Era o início de uma atmosfera política de renovação. ${ }^{11}$ Este movimento viria a divulgar o projecto de "Estados-Unidos da Europa" como algo exequível e solução para garantir a paz e a democracia.

\section{O Congresso Pan-Europeu}

Ainda na sequência da acção de Coudenhove-Kalergi realizou-se em Viena o primeiro Congresso Pan-europeu ${ }^{12}$ sob a presidência conjunta de Bénès, Caillaux, Loebe, Nitti Politis e Seipel. Contou com dois mil representantes de vinte e quatro

\footnotetext{
8 Neste contexto refira-se, também, a "Carta aberta aos parlamentares franceses", escrita por Coudenhove-Kalergi, em Junho de 1924, para transmitir a ideia de que a Europa teria de se unir para fazer frente aos três grandes: URSS, EUA, Império Britânico. Esta carta terá causado profunda impressão em Briand e Herriot.

${ }^{9}$ Esta obra teria uma grande repercussão junto de políticos como Aristides Briand, Louis Loucheur, Henri de Jouvenel, Paul Painlevè, Joseph Paul-Boncour, Léon Blum, Joseph Caillaux, Édouard Herriot, Édouard Bénès, Paul Loebe, Konrad Adenauer e Seipel.

10 Esta presença seria marcada de forma visível pelo emblema com a cruz vermelha sobre um sol dourado.

${ }^{11}$ Seria este movimento que viria a impulsionar resultados encorajadores como os Acordos de Locarno, já citados neste estudo.

12 Este Congresso realizou-se de 4 a 6 de Outubro de 1926 em Viena.
} 
países e estiveram presentes as figuras mais eminentes da inteligência europeia. ${ }^{13}$ Tinha, também, a simpatia de homens políticos como Briand, Blum, Herriot, Painlevé, PaulBoncour, Dadalier, Albert Thomas, Adenauer e Sforza. Tratava-se de erguer uma Nova Europa a partir dos contributos dos grandes homens que, no passado, a tinham já defendido e, agora, são relembrados: Carlos Magno, Sully, Abade de Saint-Pierre, Kant e o seu Projecto de Paz Perpétua, Mazzini, Nietzsche, Victor Hugo e a ideia dos "Estados-Unidos da Europa"... Intelectuais e políticos davam força ao novo impulso que agora pretendia ser dado. Dos trabalhos desse Congresso sairia o que ficou conhecido por Manifesto de Viena, e que dizia o seguinte:

“A comunhão de interesses pavimenta o caminho que conduz à comunidade política. A questão europeia é esta: é concebível que sobre a pequena quase ilha europeia, vinte e cinco Estados vivam lado a lado em anarquia internacional sem que tal estado de coisas conduza à mais terrível catástrofe política, económica e cultural? O futuro da Europa depende da resposta que seja dada a esta questão. Ele está, pois, entre as mãos dos europeus. Vivendo em estados democráticos, somos todos co-responsáveis da política dos nossos governos. Não temos pois o direito de nos limitar à crítica; temos o dever de contribuir para a realização do nosso destino político... $" 14$.

Em 1927 o movimento passará a ter como presidente de honra Aristides Briand, que prepararia a sua actuação futura na SDN, como veremos à frente. A União PanEuropeia, como projecto político federativo que era, tinha linhas programáticas bem definidas, como pode ler-se no seu programa:

“A União Pan-europeia organiza o movimento federalista europeu independentemente de todos os partidos.

Ela exige:

1. A confederação europeia com garantia recíproca de igualdade, segurança e soberania de todo os estados europeus.

13 Devem destacar-se os nomes de Benedetto Croce, Paul Valéry, Sigmund Freud, Rainer Maria Rilke, Arthur Schnitzler, Albert Einstein, Herman Von Keyserling, Selma Lagerlof, Ortega y Gasset, Miguel de Unamuno.

14 Citado por João Mota Campos, Direito Comunitário, vol. I, Lisboa, Fundação Calouste Gulbenkian, 1989,p. 32. 
2. Um tribunal federal europeu para regular todos os conflitos entre os Estados europeus.

3. Uma aliança militar europeia, com uma força aérea para garantir a paz e o desarmamento equilateral.

4. A criação progressiva da União Aduaneira Europeia.

5. A entrada das colónias dos estados europeus como valor em comum..

6. Uma moeda europeia.

7. O respeito pelas civilizações nacionais de todos os povos da Europa, fundamento da comunidade de cultura da Europa.

8. A protecção de todas as minorias nacionais e religiosas da Europa, contra a desnacionalização e opressão.

9. A colaboração da Europa com outros Estados no quadro duma Sociedade das Nações Universal”.

(A União Pan-europeia

Organismo Central: Viena, 1926) ${ }^{15}$.

Paralelamente a esta União Pan-Europeia de carácter claramente federativo, é de referir que Coudenhove procurou, também, fundamentar uma união do tipo cultural, assente nos princípios fundacionais da civilização europeia: a herança grega e cristã. Encontrou neles a base para construir uma cultura e um espírito comuns. Podia, por isso, entenderse como o seu projecto. Além de políticos, conseguiu a adesão de intelectuais, como, por exemplo, Paul Valéry, Paul Claudel, Rilke, Jules Romains, Thomas Mann, Heinrich Mann, Rainer Rilke, Victor Hugo, Von Hofmannsthal, Stefan Zweig, Arthur Schnitzler, Selma Lagerlof, Guglielmo Ferrero, Max Reinhardt, Freud, Ortega y Gassete Miguel de Unamuno. Palavras como as que encontramos na obra Vers la Paneurope, mostram bem a sua preocupação em criar uma Europa em todas as dimensões, para convencer da necessidade deste todo europeu:

"Para existir um dia sobre a carta política, a Pan-Europa deve enraizar-se no coração e no cérebro dos europeus. É necessário que de povos a povos, indústrias a indústrias, literatura a literatura, associações a associações, os pontos sejam lançados, amizade,

15 “Traci programme du mouvement en 1926”; in Information Historique, n. ${ }^{\circ 2}$, 1981, p. 58, nossa tradução. Citado por Gérard Bossuat, Les Fondateurs de l'Europe, Paris, Editions Belin, 1994, p. 27. 
interesse, compreensão mútua. O sentimento da comunidade pan-europeia, o patriotismo pan-europeu devem coroar e completar o sentimento nacional.

A Europa não pode esperar que os seus governantes e chefes dos partidos políticos se dêem conta da necessidade dela se unir. Cada homem, cada mulher, convencidos da necessidade da Pan-europa devem pôr-se ao serviço desta ideia da qual depende o destino do continente e o destino de uma civilização". 16

Os resultados da acção de Coudenhove-Kalergi revelar-se-iam, verdadeiramente, encorajadores. Não só foi recebido com entusiasmo como viria a influenciar, efectivamente, políticos e economistas seus contemporâneos. Refira-se, especificamente, o então ministro dos Negócios Estrangeiros Francês, Herriot, que lançaria no parlamento um apelo à União da Europa ${ }^{17}$, ou, a nível económico, a repercussão de Kalergi na ideia da criação de uma União Económica e Aduaneira Europeia. Defendida, primeiro, por economistas e concretizada, depois, por Loucheur, em 1927, enquanto ministro e onde propõe serem os governos a instituírem uma união de carvão, do aço e de cereais, que servisse os seus interesses comuns. ${ }^{18}$ Do ponto de vista da acção política, o movimento pan-europeu veio divulgar uma organização federativa da Europa, tendo em vista a cooperação nos domínios político, jurídico e cultural. Por último, e fundamento de todos os outros, a Pan-Europa tinha sempre como objectivo principal preservar a paz. Coudenhove-Kalergi marcaria decisivamente os anos vinte, vindo o seu pensamento político a ter repercussões, também, nos anos seguintes, particularmente após a segunda grande guerra.

\section{O Projecto Briand na Sociedade das Nações}

Após a acção de Coudenhove-Kalergi, prolongada pelo Congresso de Viena e acções seguintes da união pan-europeia, é chegada a hora política de Aristides Briand agir enquanto Ministro dos Negócios Estrangeiros. Decide, pois, tomar a iniciativa de continuar as acções já empreendidas, e das quais tinha sido além de um interessado observador, presidente do congresso pan-europeu (1927), apresentando no seio da

\footnotetext{
16 Coudenhove-Kalergi, Vers la Paneurope, Paris, 1927, in Gérard Bossuat, op. cit., p. 27.

17 Foi Édouard Herriot o primeiro a defender a concretização política dos "Estados-Unidos da Europa". Num discurso ao Senado, a 25 de Janeiro de 1925, afirmaria que "o meu maior desejo é ver um dia surgirem os Estados-Unidos da Europa".

18 É curioso observar que, desde cedo, esteve bem presente a ideia de que uma união europeia seria mais fácil de concretizar se começasse por unir interesses económicos, e só mais tarde prosseguisse pelo aprofundamento político. Uma ideia dos anos vinte do século XX que permanece actual no século XXI.
} 
Sociedade das Nações um projecto de União Europeia, primeira tentativa governamental de realizar a unidade europeia. É uma iniciativa de carácter oficial e político, que a torna, no momento, a mais arrojada e, por isso, será alvo, como veremos, das maiores reservas. Note-se, porém, que antes de apresentar em Assembleia Geral, Aristides Briand tinha auscultado políticos influentes, que a acolheram com interesse, excepção feita à Grã-Bretanha, que, desde logo, manifestara reservas. De qualquer forma, tinha obtido o voto favorável do parlamento francês e uma opinião pública favorável ao apresentar a sua ideia em Conferência de Imprensa. Assim, a 5 de Setembro de 1929 será a vez de submeter o seu projecto de União Europeia à Assembleia Geral da SDN:

" Tenho-me associado, nestes últimos anos, a uma propaganda activa a favor de uma ideia que alguns têm pretendido qualificar de generosa, talvez para se dispensarem de a qualificarem como imprudente.

Esta ideia, que nasceu há muitos anos, que tem povoado a imaginação de filósofos e de poetas, valendo-lhes o que se poderia apelidar de sucesso de estima, tem penetrado nos espíritos por força do seu próprio mérito. E acabou por surgir como resposta a uma necessidade. Os propagandistas reuniram-se para a difundir, para a fazer ir mais longe no espírito das nações e confesso que me encontrava entre estes propagandistas.

No entanto, nunca me iludi quanto às dificuldades de tal projecto, nem descurei os inconvenientes que podem advir para um homem de Estado ao lançar-se no que se poderia qualificar como uma aventura (...).

Penso que entre povos que estão geograficamente agrupados, como os povos da Europa, deve existir uma espécie de laço federal; estes povos deverão ter a possibilidade de, a qualquer momento, entrar em contacto, discutir os seus interesses, tomar resoluções comuns, estabelecer o vínculo de solidariedade, que lhes permita fazer face, no momento oportuno, a eventuais circunstâncias graves. É este o laço que eu desejaria esforçar-me por estabelecer.

Evidentemente a associação terá, sobretudo, lugar no domínio económico. É esta a questão mais urgente e eu creio que é possível alcançar êxito. Mas estou igualmente seguro de que, do ponto de vista político, assim como do ponto de vista social, o laço federal, sem afectar a soberania de nenhuma das Nações que possam vir a participar em tal associação, pode ser benéfico. Atrevo-me a pedir aos meus colegas que aqui representam as nações europeias que considerem oficialmente esta sugestão e a 
proponham para estudo aos vossos governos, a fim de mais tarde, talvez na próxima sessão da Assembleia, se decidir sobre as possibilidades da sua realização" ${ }^{\text {19 }}$.

Repare-se o "cuidado" na apresentação da proposta de Briand que, no contexto em que é apresentada, só seria recebida se fosse usada grande diplomacia; seria isso que justificaria que Aristides Briand por um lado falasse de "laço federal" entre os povos da Europa, e, por outro, que seria mantida intacta a soberania das Nações. O que torna, sem dúvida, pelo menos equívoca, a sua proposta, assim como será a sua recepção. Como compatibilizar um laço federal entre os Estados da Europa com o respeito pela soberania dos mesmos?

Este discurso, à excepção de Gustav Stresemann, ministro alemão dos Negócios Estrangeiros, que o recebeu calorosamente, recebeu um acolhimento bem mais reservado. Embora o seu autor fosse felicitado, não faltavam, como era de esperar, as objecções. Alguns, como Léon Blum, observavam as aparentes contradições do projecto; outros nem sequer queriam pensar na sua possível contradição. Mas os mais reservados continuavam a ser os Britânicos que pareciam gostar mais da ideia de Império do que da ideia de Europa. No entanto, Churchill não se opunha, frontalmente, à iniciativa, embora deixasse claro que estava com a Europa mas não era da Europa, ou seja, estava ligado mas não incluído ${ }^{20}$.

A proposta de união federal europeia era, pelo menos, equívoca. Por isso, nem podia ser aprovada de imediato, nem recusada totalmente. Foi pedido ao seu autor que explicasse melhor o seu plano de unidade europeia, e o enviasse, depois, a todos os vinte e sete estados europeus presentes na SDN. A partir desse documento, todos os governos teriam, então, de pronunciar-se.

\section{O Memorandum Briand de 1 de Maio de 1930}

$\mathrm{Na}$ sequência desse "convite" a precisar melhor os seus objectivos, Briand apresentaria o seu pensamento sobre o assunto num texto que ficaria conhecido como Memorandum Briand. Redigido pelo secretário-geral do Quai d'Orsay, Alexis Léger, não esclarecia as grandes apreensões anteriores, pelo contrário parecia acentuar, agora,

\footnotetext{
19 Aristides Briand,"Discours devant l'Assemblée générale de la SDN, 5 de Septembre1929”, JO da SDN, décima sessão, Genebra, 1929.

20 Repare-se que esta atitude de Churchill não variará. Após a Segunda Guerra será um dos mais entusiastas a favor de uma Europa Unida, sem, no entanto, comprometer a Inglaterra... Continuará, então, a acreditar nas potencialidades do Império Britânico...
} 
o peso do político sobre o económico. Estava em causa, como vimos, a (in) conciliação entre o "laço federal" entre os Estados e inviolabilidade da sua soberania. No entanto, o memorandum em vez de refrear a ideia de "união federal entre os estados" ou substituir, pelo menos, as expressões usadas por outras mais suaves que fizessem parecer a sua proposta mais "aceitável", continua a insistir na proposta de instituir entre os povos europeus essa união política. Na verdade, o novo documento não apresenta nada de verdadeiramente novo ao apresentado na Sociedade das Nações; mantém inalterável quer a forma quer o conteúdo anterior, continuando a insistir em que deva existir " entre os povos da Europa uma espécie de laço federal" mas que, no entanto tal não vai "afectar os direitos soberanos dos Estados-Membros de uma tal associação de facto". Propondo uma "União Federal Europeia", dizia, no entanto, tratar-se apenas da constituição de uma "solidariedade entre os governos europeus"! A ambiguidade da proposta de Aristides Briand era ainda acrescentada. Leiamos as suas palavras:

"Não se trata de modo algum de realizar peça por peça uma construção ideal respondendo abstractamente a todas as necessidades lógicas de um vasto esboço de mecanismo federal europeu, mas, bem pelo contrário, de evitar qualquer ideia feita; importa, antes, uma vinculação em termos práticos quanto à realização efectiva de um primeiro sistema de contacto e de solidariedade constantes entre os governos europeus, com vista à resolução em comum de todos os problemas relativos à organização da paz europeia e do ordenamento racional das forças vitais da Europa"21.

$\mathrm{O}$ memorandum procurava responder às necessidades de um tempo ameaçado pela guerra, e de uma Europa que precisava de coordenar as suas forças políticas, morais e económicas. Daí a justificação de estabelecer um "laço entre as Nações europeias", mas que não punha de modo nenhum em causa os "direitos soberanos dos Estados membros duma tal associação de facto", respeitando a integridade de cada nação ${ }^{22}$. O governo francês pedia aos estados uma resposta formal a questões concretas que lhe eram formuladas, e que aqui não podemos desenvolver, mas que justificam uma certa "uniformidade" nas respostas obtidas. Os governos tinham o dia 15 de Julho como

\footnotetext{
21 Mota Campos,op.cit., p.33.

$22 \mathrm{Cfr}$. Documents relatifs à l' organization d'un régime d' union fèdèrale européenne,MNE, Arquivo Histórico-Diplomático, 3P/A1/M545.
} 
data limite para se pronunciarem, dado que era urgente tomar uma decisão sobre o destino da Europa. ${ }^{23}$

\section{Portugal e a resposta diplomática ao plano Briand}

Não cabe neste estudo fazer uma apreciação de todas as respostas ao plano Briand $^{24}$. Vale, no entanto, a pena dizer que a ideia parecia simpática e teve, por isso, uma recepção correspondente ao nível em que foi apresentada. Porém, as formalidades diplomáticas que se seguiram, onde já estavam comprometidas as respostas dos governos, eram diferentes, ou, pelo menos tão vagas quanto o próprio plano Briand. Excepção, novamente, feita à Grã-Bretanha. Embora não rejeitasse, claramente, a proposta, na prática tal significava, ao não considerar necessário criar novas "instituições internacionais". Pela verdadeira diplomacia subjacente à resposta, importa citá-la:

" Em relação aos métodos propostos pelo governo francês para a realização do seu desígnio, o governo de Sua Majestade no reino unido experimenta mais dificuldades. Não está convencido de que um exame conduzido com pleno conhecimento de causa venha a mostrar que o estabelecimento de instituições internacionais novas e independentes seja necessário ou desejável. Para além do problema muito difícil da coordenação, o governo de Sua Majestade do reino unido considera possível que uma União Europeia exclusiva e independente, da natureza da que é proposta, acentue ou suscite tendências a rivalidades e hostilidades intercontinentais que importa, no interesse geral, diminuir ou evitar. O governo francês compreenderá certamente que existem a este respeito razões particulares que o governo de Sua Majestade no Reino unido deverá tomar em conta na sua qualidade de membro da Comunidade Britânica..." ${ }^{25}$.

As outras reacções dividiram-se entre as claramente favoráveis, como a Jugoslávia e a Bulgária e favoráveis com reservas, como era o caso dos Países Baixos, Noruega e Grécia, assim como dois aliados de França, a Checoslováquia e a Polónia.

\footnotetext{
23 Vale a pena ler na integra o documento citado no $\mathrm{n}^{\circ}$ anterior e que por falta de espaço não podemos desenvolver.

24 A esse propósito deve ler-se o estudo de António Martins da Silva, "A ideia de Europa no período entre as duas guerras. O Plano Briand e o posicionamento português", Revista de História da Sociedade e da Cultura, 2, 2002, pp. 85-151.

25 Mota Campos, op. cit., p.34.
} 
Finalmente, os outros mostravam-se, pelo menos, tendencialmente, desfavoráveis. As objecções ao documento eram, sobretudo, sobre a questão do problema dos limites geográficos da Europa (devia incluir-se a Turquia? A URSS?), e da vontade de preservar a soberania dos Estados. Por outro lado, outros questionavam-se sobre a perda de influência da própria SDN ao ser criada um "agrupamento" de Estados dentro da própria organização de carácter universal. Fora da Europa, o plano foi mal recebido, se mais razões não existissem por meras questões económicas.

A proposta de Aristides Briand suscitaria uma resposta diplomática por parte de Portugal, que aqui interessa abordar ${ }^{26}$. Toda a documentação do Arquivo Histórico Diplomático relativa a este assunto mostra como o governo português ia sendo informado de tudo quanto se ia passando, para que pudesse tomar uma posição sobre o assunto. As legações dos países mais significativos davam conta da recepção desse plano e provável resposta desses governos ${ }^{27}$. Parecia claro que a Bélgica daria a sua adesão à proposta francesa e que da Itália surgiriam muito mais objecções. As notícias diplomáticas que chegavam da Legação de Portugal em França são, sobretudo, sobre a recepção da Alemanha ao memorandum, que não excluindo a possibilidade de uma "União federal europeia", critica especificidades do documento e deixa claro todas as concessões que lhe terão de ser feitas ${ }^{28}$. E pela mesma legação teríamos conhecimento da resposta irlandesa, considerada a mais parecida com o caso português nas objecções que aponta ${ }^{29}$. Por último, interessa referir o ofício recebido de Estocolmo, que parece indiciar o " fracasso" deste projecto ${ }^{30}$.

Quanto à resposta portuguesa, o governo iria pronunciar-se a 12 de Julho de 1930, num documento intitulado " Resposta do governo português ao memorandum Briand" $^{31}$, que desenvolveremos de seguida. A resposta revela bem o teor político da resposta. Mostrando-se muito interessado e quase empenhado na "causa europeia", diz

\footnotetext{
26 Deve no entanto referir-se que este plano teve grandes repercussões na opinião pública, sendo de referir o papel da imprensa portuguesa em veicular tal proposta. São abundantes as notícias sobre o assunto em vários jornais que não cabe aqui tratar. Este estudo já está feito por António Martins da Silva, " A ideia de Europa no período entre as duas guerras. O plano Briand e o posicionamento português", Revista de História da Sociedade e da Cultura, 2,2002, pp.85-151. Veja-se, especificamente, o ponto 2: "A opinião pública face à proposta de Briand e ao memorando francês":

27 Veja-se, por exemplo, os ofícios A/108 da Legação de Portugal em Bruxelas, 7/6/1930, MNE, AHD, 2P/A4/M226 e da legação de Portugal em Itália, de 15/7/1930, MNE, AHD, 2P/A4/M226.

28 Ofício da Legação de Portugal Em França, A-131 de 18/7/1930, MNE/AHD, 2P/A4/M226.

29 ibidem, A 138 de 22 /7/1930, 2P/A4/M226.

30 Ofício da Legação de Portugal em Estocolmo, de 31/7/1930, MNE/AHD/2P/A4/M226.

31 "Resposta do Governo Português ao Memorandum Briand", MNE/AHD/2P/A4/M226.
} 
estar "sempre pronto a colaborar em todos os esforços que tendam para a consolidação da paz e para a solução dos problemas interessando de maneira geral aos diferentes povos. Portugal está, em princípio, disposto a examinar em conjunto com os outros Estados Europeus convidados os pontos indicados no Memorandum do Snr.Briand. Julga porém indispensável em primeiro lugar, que, no próprio intuito de não prejudicar a realização dos objectivos que se têm em vista, o estudo de tais problemas seja feito de maneira gradual e somente na extensão em que é lícito supor uma probabilidade de êxito superior ao malogro da discussão. Entende também o Governo português ser imprescindível consignar que o pensamento de um laço ou União Federal entre os povos da Europa não pode envolver a menor ideia de quebra ou diminuição de independência e de integridade política, ou de delegação, por qualquer deles, dos direitos inerentes à sua soberania",32.

Parece ser óbvia a resposta, cujas interpretações são desnecessárias. Acrescenta, ainda, que em qualquer caso, Portugal não prescindirá das suas colónias e das raízes históricas que o ligam ao Brasil, de laços de amizade ou alianças com outros estados, e espera não seja enfraquecida a acção da SDN, e que acordos económicos não exijam concessões políticas. Sumariamente é este o teor da resposta portuguesa, que mostra bem como está longe do horizonte a aspiração dos Estados-Unidos da Europa, acima de tudo porque Portugal não se considera uma nação exclusivamente europeia, sendo que a sua vocação parece inclinar-se pelo atlântico. As sugestivas palavras de Luíz Sampaio, secretário-geral da Direcção política do Ministério dos Negócios Estrangeiros, fariam uma espécie de balanço final sobre o Plano Briand ${ }^{33}$ Com a concordância do ministro, Fernando Branco, enviaria para a delegação de Portugal junto da Sociedade das Nações, chefiada por Augusto de Vasconcelos, um parecer confidencial que completa o quadro anterior. Portugal aspira pela não progressão nem política, nem sequer económica do projecto de União Europeia: “ Embora o êxito do plano Briand não pareça vir a ser tal que deva assustar-nos, a prudência manda-nos precaver contra as surpresas que podem surgir nas diferentes etapas já marcadas para a sua marcha: reunião parlamentar,

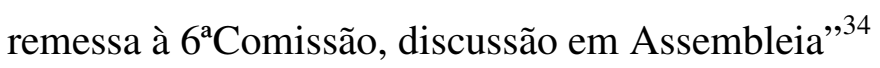

\footnotetext{
32 Ibidem, pp-1-2.

33 "Parecer da Direcção Política sobre o Plano Briand", de 3 de Setembro de1930,MNE/AHD,2P/A4/M226.

34 Ibidem, p.1.
} 
Portugal mostra recear este projecto, que, apresentado pela França não parecia condenado à partida, e era, por isso, necessário acautelar em termos diplomáticos.

\section{A Comissão de Estudo para a União Europeia}

E a proposta anterior, nem aceite nem recusada liminarmente, acabaria para seguir para "Estudo". Sem pressas, só em 17 de Setembro de 1930 seria nomeada, durante a undécima sessão da Assembleia da SDN, a Comissão de Estudo para a União Europeia $^{35}$, presidida pelo próprio autor do plano para Europa ${ }^{36}$ que estudaria o assunto durante dois anos, ou seja, até à sua morte. Cabia a esta Comissão fazer progredir o plano Briand, partindo do memorandum francês de 17 de Maio de 1930 e respectivas respostas dos governos a quem tinha sido enviado. Após estudar o assunto, a Comissão deveria apresentar um relatório dos resultados a que chegara, durante a próxima Assembleia da SDN. É ainda de referir que, dado esta comissão especial pertencer à SDN, nela podiam participar todos os seus membros, e não apenas aos europeus cujo assunto lhes pertencia. Estava, pois, aberta a possibilidade de qualquer entendimento ou colaboração entre eles ${ }^{37}$. Curiosamente, como bem observa Pierre Gerbet, durante a primeira sessão de trabalhos da Comissão, realizada a 23 de Setembro de 1931, Briand foi eleito seu presidente e o secretariado foi entregue ao britânico, Eric Drummond, secretário-geral da SDN, que parecia a pessoa certa para não fazer progredir o projecto do governo francês ${ }^{38}$. Mas outros governos contribuiriam, como veremos, para que o estudo da união europeia não avançasse.

35 Esta designação de "Comissão de Estudo para a União Europeia” só seria dada na primeira sessão de trabalhos deste grupo de trabalhos, entretanto, designado na Assembleia da SDN de "Comissão Especial".

36 Como vimos, o Plano Briand viria a ter as seguintes etapas:

5 de Setembro de 1929- Discurso de Aristides Briand na X Assembleia da SDN, em Genève.

9 de Setembro de 1929- Almoço no Hotel des Bergues, em Genève, onde é confiado ao governo francês a elaboração de um memorandumsobre uma união política.

1 de Maio de 1930- É apresentado a todos os governos europeus o memorandum. Junho-Julho de 1930- Respostas dos vinte e seis governos.

Agosto de 1930- Relatório do governo francês sobre os resultados do projecto de uma união federal europeia.

17 de Setembro de 1930- Resolução da XI Assembleia da SDN sobre a criação de uma Comissão de Estudos para a União Europeia.

37 A este propósito deve ler-se o Rapport du Secrétaire générale à l'Assemblée sur l'oeuvre accomplie par la Comission d'Étude pour l'Union Européenne, 26 de Junho de 1931, AHD,3P/A1/M545.

38 Pierre Gerbet, La Construction de l' Europe, Paris, Impremerie Nationale, 1983, p.42. 
Portugal faria representar-se nessa Comissão por Augusto de Vasconcelos, chefe da delegação portuguesa na SDN, e Lobo d'Ávila Lima, técnico do MNE. O relatório do primeiro mostra como apesar de tudo, o projecto do Senhor Briand foi retomado, mas, essencialmente, o desinteresse real pela federação europeia mantinha-se ${ }^{39}$. O interesse deste relatório reside em apresentar os assuntos tratados durante as reuniões da Comissão de Estudos, realizadas de 16 a 20 de Janeiro desse ano, como, também, em revelar a importância da diplomacia paralela dos bastidores, com repercussões decisivas nos resultados alcançados. Era evidente para a nossa delegação, que a presença dos vinte e dois Ministros dos Negócios Estrangeiros e de alguns presidentes do Conselho, não era equivalente ao interesse pelo plano do Senhor Briand. Vinham por motivos de cordialidade diplomática, mais do que por manifesto interesse pelo projecto.

Durante a segunda sessão vários obstáculos seriam apresentados pelos diversos governos, que punham em causa não só uma organização política da Europa, como também, o seu desenvolvimento a nível económico. Representando a posição italiana, o Senhor Grandi mantinha a posição manifestada no memorandum, defendendo uma união de toda a Europa, e não só dos membros europeus da Sociedade das Nações, querendo referir-se à inclusão sobretudo da Rússia e da Turquia ${ }^{40}$ :"Convidar um estado (refere-se ao caso soviético), que tem sempre declarado, que não quer fazer parte da SDN, a ser um dos membros efectivos dessa mesma sociedade, era evidentemente um paradoxo constitucional. E o Senhor Grandi não soube responder à objecção" ${ }^{\text {"41 }}$. E nesta linha de união e de solidariedade de toda a Europa, propunha, ainda, uma igualdade política de todos os estados e ao nível da segurança uma redução geral dos armamentos, como previsto no pacto e a manutenção da vocação universal da SDN, que não devia ser afectada por via dos projectos europeus. Esta posição era considerada de interesse para a delegação inglesa que propunha o seu estudo atento ${ }^{42}$. A Alemanha aproveitaria para reivindicar, também, a salvaguarda dos seus interesses específicos, ligados à defesa das minorias e libertação da pátria, que permitisse uma verdadeira igualdade entre estados, embora num tom cordial que contrastando com o italiano, permitia pensar ainda num

\footnotetext{
39 Relatório de Augusto de Vasconcelos, chefe da Delegação de Portugal junto da SDN, 30 de Janeiro de 1931, MNE/AHD, 3P/A1/M545. Por falta de espaço não podemos, aqui, desenvolver o desenrolar dos trabalhos desta Comissão.

40 Esta pretensão era totalmente desajustada já que estes países nem sequer faziam parte da SDN, o que seria juridicamente impossível! Esta foi a defesa encontrada por Brians, que, afinal, sempre desejara que os "Estados Unidos da Europa" surgissem à margem da SDN...

41 Relatório de Augusto de Vasconcelos, 30 de Janeiro de 1931,AHD/MNE, 3P/A1/M545, p.1.

42 Carta da legação de Portugal em Roma, de 17 de Janeiro de 1931, MNE/AHD, 3P/A1/M545.
} 
entendimento político europeu. Mas ia tornando-se claro que esse entendimento só poderia passar pelas questões económicas, e que o horizonte político, afinal na génese do projecto Briand estava cada vez mais longe de ser alcançado. Assim, ficaria decidido que se convidariam, também, os Estados europeus não membros da SDN a participarem nos "dossiers" exclusivamente económicos. Foi esta a resolução tomada e redigida por Henderson, que voltava a implicar a inclusão da Rússia, o que seria recusado por oito $\operatorname{estados}^{43}$.

E os debates económicos continuariam com a proposta apresentada pelo holandês, Colijn, de aprovar uma cooperação económica que culminaria com a aprovação de uma convenção comercial, já elaborada em Março de 1930. Seria aqui que Portugal manifestaria a sua reprovação, não assinando a referida convenção, recusada quer pela delegação portuguesa, quer, depois, pelo próprio Ministro dos Negócios Estrangeiros, Caeiro da Matta. Estavam em causa os interesses económicos portugueses que tinham de ser acautelados, porque Portugal embora europeu, tinha interesses marcadamente atlânticos. Assim, “ apareceu de facto a moção: na sua conclusão IV lá estava o convite para a assinatura da preconizada Convenção. Formulei a devida reserva, reportando-me ao discurso da véspera. A nossa acção ficou tão livre de compromissos como anteriormente estava" 44 .

A Comissão de estudo terminaria os seus trabalhos sem resultados políticos significativos, à excepção da aprovação de um manifesto pela paz, da autoria do próprio Briand, apresentado por França, Inglaterra, Alemanha e Itália. A maioria esmagadora das resoluções seriam sobre matérias económicas, o que levaria o chefe da legação de Portugal em Roma a concluir que “ a pomposa Conferência da União Europeia modestamente se transforma em simples conferência económica (...); e é claro que a União Europeia, que já era um artifício, passa a ser uma ficção e um mito. Os Estados Unidos da América podem ainda contemplar de palanque os Estados Desunidos da Europa" $"$.

Nessa altura, também, a proposta Briand parecia não poder continuar de pé, até porque as condições políticas se revelavam inóspitas a Uniões, e mais próprias ao

\footnotetext{
43 A recusa viria da Noruega, Bélgica, Dinamarca, Espanha, Paises-Baixos, Suécia, Suiça e Jugoslávia.

44 Relatório de Augusto de Vasconcelos, 30 de Janeiro de 1931, MNE/AHD/M545, p.IV.

45 Carta da Legação de Portugal em Roma, de 21 de Janeiro de 1931, AHD/MNE, 3P/A1 /M545.
} 
despontar de novos nacionalismos e à iminência de uma nova guerra. ${ }^{46}$ Apesar de durante os anos trinta ainda se ter mantido viva a chama europeia, por via da acção do Movimento da Pan-Europa, que Coudenhove-Kalergi persistia em afirmar, nomeadamente com a realização dos Congressos Pan- Europeus, essa Europa continuava a ser uma miragem. Ainda não tinha chegado a hora de concretizar a almejada união Europeia. Particularmente para Portugal nem havia necessidade de fazer-se representar. Afinal as suas preocupações estavam bem distantes: sendo um pequeno país europeu, considerava-se uma grande potência colonial.

\section{II - Portugal e a Construção Europeia após a segunda guerra}

Como vimos na primeira parte deste estudo, Portugal nunca ignorou os acontecimentos europeus, sendo mesmo convidado a pronunciar-se diplomaticamente sobre as ideias de unidade europeia em curso, no período pós-primeira guerra. O mesmo sucederia a seguir ao segundo grande conflito mundial, perante uma Europa arruinada, cuja palavra de ordem, lançada por Winston Churchill, seria "Construir a Europa"47. Não se tratava apenas de um apelo à união dos povos europeus, na sequência dos projectos lançados anteriormente, mas sim de uma necessidade absoluta de reconstrução europeia. A este propósito, as notícias na imprensa são abundantes, e não cabem no enfoque seleccionado nesta reflexão ${ }^{48}$. No entanto, a imprensa acaba por reflectir o que se passa a nível diplomático.

\section{O Congresso da Haia}

É pela leitura da caixa de documentação da Legação de Portugal em Haia, que podemos perceber os ecos do que se tinha passado no Congresso de 1948, e a posição de Portugal sobre este assunto. Assim, ainda antes do Congresso, a 6 de Janeiro de 1948, aquela legação informava o Ministro dos Negócios Estrangeiros Português, da vinda de Hendrik Brugmans a Portugal. Este presidente da União Europeia dos

\footnotetext{
${ }^{46}$ De facto com a subida ao poder de Hitler mais correcto seria falar da construção de um tipo de união pela força do que da união livre dos diversos povos da Europa.

${ }^{47}$ Discurso de Winston Churchill pronunciado em Zurique, a 19 de Setembro de 1946, in 60 Anos de Europa. Os Grandes Textos da Construção Europeia, Lisboa, Parlamento Europeu, 2008.

48 A este propósito leia-se o estudo de António Martins da Silva, "Portugal e a unidade europeia no pósguerra (1945-1948): reacções e tomadas de posição", Revista Portuguesa de História, t.XXXII (19971998), Coimbra, Faculdade de Letras, 1998.
} 
Federalistas tinha como objectivo interessar o governo português neste movimento federalista e convidá-lo a fazer-se representar em Haia em 7 de Maio desse ano. No entanto, estava também interessado em conquistar a opinião pública, representada pelo mundo da comunicação, universitário, religioso e sindical. São suas as seguintes palavras:

"Embora interessado no apoio do governo, estimaria, sobretudo, tomar contacto com representantes das Universidades, do Jornalismo, da Igreja e dos sindicatos... a delegação portuguesa ao congresso teria a sua posição mais fortalecida se incluísse também personalidades não nomeadas pelo governo"49.

Nas entrelinhas deste ofício, percebe-se claramente como se pretendia conquistar a opinião pública e as dúvidas, ou certezas, sobre a falta de adesão política portuguesa a este projecto. Aliás, esse facto é evidente se lermos a correspondência do ministro de Portugal em Bruxelas, Eduardo Leitão, sobre o facto de todos os países já terem indicado os seus representantes no referido congresso à excepção de Portugal. Por isso, a 10 de Março, o Dr. Roetinguer, Secretário Geral do Comité de Coordenação para a Organização da Europa, desconhecia a composição do comité português ${ }^{50}$. Seria esquecimento ou opção diplomática?

De facto, Portugal estaria presente em Haia, de 7 a 10 de Maio de 1848, mas, sem representação governamental. Apenas estariam representados os católicos portugueses, através do seu único delegado, como pode ler-se em ofício do diplomata português da Legação de Portugal em Haia:

“Tive ocasião de conhecer pessoalmente o antigo secretário de Estado do Foreign Office. O Senhor Edden foi muito amistoso e referiu-me duas intervenções que tivera, quando presidia à Comissão política do Congresso, a favor de Portugal e da Espanha depois confirmadas pelo delegado dos católicos portugueses.Não sei que orador fizera referência à ausência dos povos da Península - o que levou o único delegado português a recordar que representava os católicos portugueses e que o Governo de Portugal aderira às decisões da Conferência dos 16, em Paris. O senhor Eden comentou publicamente que, na verdade, estando representados os católicos, estavam, praticamente, representados todos os portugueses. Ficou assim encerrado este

\footnotetext{
49 Ofício da Legação de Portugal na Haia, de 6 de Janeiro de 1948, proc.33,12, MNE, AHD, 2P/A50/M39-A.

50 Veja-se o Ofício da Legação de Portugal em Bruxelas, de 10 de Março de 1948, proc. 33,12, MNE, AHD, 2P/A50/M39-A.
} 
Incidente que talvez mostre ter sido pena não se haverem deslocado à Haia mais delegados de Portugal",51.

No contexto político da época em Portugal, compreende-se bem esta ausência e este silêncio. São conhecidas as ideias de Salazar sobre esforços de unificação europeia, e, sobretudo a visão estratégica para Portugal. Parecia-lhe fora de possibilidade a ideia de uma Europa federal, e, claro, mais ainda, a sua possibilidade de realização. Todos os seus discursos sobre o assunto iam nesse sentido, como é sobejamente conhecido, e não cabe aqui desenvolver. Aliás, o que estava em causa não era uma unidade cultural da Europa, mas uma unidade política, como esclarece o Ministro da Legação Portuguesa em Haia:

“O antigo Ministro dos Negócios Estrangeiros da Grã-Bretanha mostrou-se interessado em saber como reagia o Governo Português à ideia de Unidade da Europa. Disse-lhe ser minha convicção pessoal que o Governo do meu país - sempre pronto a colaborar em tudo o que representasse a defesa do património espiritual ou reconstrução económica da Europa - não parecia, contudo, muito crente nos benefícios de uma mística continental e na criação de super-organismos que limitassem as soberanias nacionais dos diversos países da Europa"

\section{Comité Internacional de Coordenação dos Movimentos para a Unidade Europeia}

$\mathrm{Na}$ sequência do Congresso da União Europeia, outras iniciativas de cariz federalista foram surgindo. São de salientar o Comité Internacional de Coordenação dos Movimentos para a Unidade Europeia, mais tarde designado como Movimento Europeu, e a União Parlamentar Europeia, ainda mais radical.

O Comité Internacional de Coordenação dos Movimentos Europeus estabeleceu como prioridade estudar a possibilidade de adoptar as resoluções de Haia, nomeadamente relativas à criação de uma Assembleia Europeia. Seria a partir desta instituição que se viabilizariam os esforços necessários para a realização da Unidade Europeia. Neste sentido, aquele comité enviaria a todas as nações signatárias da Convenção para a Cooperação Económica Europeia, um memorandum a propor que aquela Assembleia se reunisse para dar inicio aos trabalhos, o mais tardar no início de

51 Ofício da Legação de Portugal na Haia, nº562/226, de 2 de Julho de 1948, p. 10, MNE, AHD, 2P/A50/M39-A.

52 Ofício da Legação de Portugal na Haia, n562/226, de 2 de Julho de 1948, p.11, MNE, AHD, 2P/A50/M39-A. 
1949. Nesse sentido, Portugal seria convocado por carta datada de 19 de Julho de 1948 , assinada por Duncan Sandys 53 .

Pelas mesmas razões já aqui referidas, o estabelecimento de uma Assembleia Parlamentar Europeia não estava nos horizontes dos governantes portugueses. Por isso, Portugal não viria a participar na organização em que a mesma se projectaria, apesar da sua legitimidade formal para $\mathrm{tal}^{54}$. Mais uma vez, não estava em causa o espírito europeu nem os valores fundamentais da cultura europeia, também partilhados por Portugal, mas a opção por um projecto político que era contrário às opções portuguesas e punha em causa a soberania das nações europeias envolvidas. Portugal não desejava abdicar de princípios políticos e de uma história e situação geográfica ímpares. Por outro lado, considerava mesmo perigosas todas as tentativas federalistas em marcha, que tendo como objectivo fundamental fazer renascer uma Europa moribunda pela guerra, podia ter resultados perversos.

\section{Congresso Parlamentar de Interlaken}

A mesma posição seria adoptada sobre o Congresso Parlamentar de Interlaken. Embora convidado a participar, Portugal escusar-se-ia a estar presente, pelas mesmas razões anteriormente apontadas. Também ali se projectava a criação de uma federação europeia, ou seja, a "Federação dos Estados Unidos da Europa" ${ }^{\text {. S5 }}$. pe por razões políticas era compreensível a ausência e o distanciamento de Portugal em relação a estes projectos, afinal, no resto da Europa o sentimento parecia ser comum, quando dos dezassete países convidados, só compareceram treze delegações diplomáticas, e só doze aprovariam as resoluções ali tomadas. A federação europeia era no passado, como no presente, uma ideia demasiado arrojada para fazer dela a pedra angular da unidade europeia. Os seus países tinham pela ideia de soberania um valor demasiado elevado para poderem aprovar a sua transferência para um modelo federal, ou mesmo, a sua partilha numa unidade menos radical.

53 Carta de Dundan Sandys, Presidente do Comité Executivo do Comité Internacional de Coordination des Mouvements pour l'Unité Européenne, 19 de Julho de 1948, MNE, AHD, 2P/A50/M39-A.

54 "Memorandum relatif à la convocation d'une Assemblée Européenne", MNE, AHD, 2P/A50/M39-A. 55 Cfr. Plan d'Action d'Interlaken pour la convocation immediate d'une Assemblée Européenne ayant pour object l'élaboration d'une Constitution des États-Unis d'Europe adopté par l'Union Parlementaire Européenne, le 4 Septembre 1948, MNE, AHD, 2P/A50/M37. 
Apesar das dificuldades sentidas e auscultadas a nível diplomático, os europeístas acreditavam na virtualidade do projecto de uma federação europeia e continuavam o seu "apostolado". Nas deliberações do Congresso pode ler-se a intenção de enviar o plano de acção aprovado aos Presidentes dos Governos, Presidentes dos Parlamentos e aos Ministros dos Negócios Estrangeiros dos países interessados. Quem seriam os verdadeiramente interessados? Na prática, o plano propunha a convocação de uma Assembleia Europeia composta pelos países membros da OECE, e que deveria realizar-se antes de 31 de Março de 1949. Antes disso, cabia a cada delegação à Assembleia providenciar para que fosse feita uma ampla campanha de esclarecimento da opinião pública sobre o projecto em causa, de forma a conquistar gradualmente a simpatia dos europeus pela ideia federalista. Os resultados sobre a receptividade dos europeus ao projecto federalista seriam comunicados e analisados pelo Conselho da União Parlamentar Europeia a realizar em Dezembro de 1948, para "tomar todas as decisões necessárias" ${ }^{, 56}$.

É interessante perceber que Portugal não tinha a "atmosfera" ideal para transmitir e entusiasmar a opinião pública por um plano que ia sentido contrário quer ao plano nacional, quer ao sentimento dos portugueses que também estavam na Europa, mas não eram da Europa. Ou seja, todos olhavam para além-mar, e, por isso, não é de estranhar a falta de adesão a ideias europeístas. É, no entanto, muito interessante constatar como Portugal era considerado um potencial membro dessa Europa Federal, já que todas as informações sobre a mesma lhe iam chegando, quer por via governamental quer pela diplomática.

Nesse sentido, o próprio Presidente da União Parlamentar Europeia envia a Salazar uma Carta sobre o "Plano de Acção" e os respectivos documentos sobre o assunto aprovado em Interlaken. Nessa carta, Georges Bohy solicitava ao Presidente do Conselho que transmitisse ao Conselho de Ministros o convite para Portugal se associar ao empreendimento europeu cujos primeiros passos estavam a ser dados. O nosso país poderia assim "colocar-se entre os iniciadores desta unidade europeia que responde simultaneamente aos sentimentos dos povos e às realidades económicas e políticas mais prementes" ${ }^{\text {"57 }}$.

\footnotetext{
56 Plan d'Action d'Interlaken pour la convocation immediate d'une Assembléee Europeénne ayant pour l'object l'elaboration d'une Constitution des États-Unis d'Europe adoptee par l'Union Parlementaire Européenne, le 4 Septembre 1948, MNE,AHD, 2P/A50/M37.

57 Carta de Georges Bohy, Presidente da União Parlamentar Europeia a António de Oliveira Salazar, 5 de Setembro de 1948, MNE, AHD, 2P/A50/M39-A.
} 
É bom recordar a figura de Coudenhove-Kalergi, secretário-geral da União Parlamentar Europeia, e um dos grandes impulsionadores da unidade europeia, sobretudo militante desta causa no período entre-guerras ${ }^{58}$. Também ele escreveria uma carta a César de Sousa Mendes, representante de Portugal na Legação em Berna. Nessa carta pode ler-se que "a União Parlamentar Europeia esperava poder organizar um Grupo Parlamentar Europeu em Portugal para se conseguir uma estreita colaboração entre Portugal e os outros grupos parlamentares, na Europa"59. Este desejo do "apóstolo" da Europa seria transmitido por César de Sousa Mendes ao Ministro dos Negócios Estrangeiros Português, mas ficaria sem resposta. A carta de CoudenhoveKalergi seria arquivada! Os Estados Unidos da Europa continuavam, tal como na actualidade, a ser um sonho por realizar.

\section{Reflexões Finais}

No passado, como no presente, a Europa tem vivido do contributo também dos portugueses, e, Portugal, especificamente representado por Lisboa, dá identidade a marcos importantes da construção europeia. Ao longo deste estudo, podemos observar como a nível diplomático Portugal foi sempre acompanhando os projectos europeus.

Embora, a outro nível, que não o político, também na esfera do pensamento, concretamente das ideias políticas, Portugal sempre mostrou uma apetência para "alimentar" o sonho europeu.

O caso mais paradigmático aconteceria logo a seguir à segunda guerra mundial, ainda no seu rescaldo, quando dias antes se consumara a vitória dos Aliados sobre o Eixo nazi-fascista. Seria um português a conseguir ter, no século XX, impacto, de certa forma, proporcional ao conseguido por Victor Hugo no século anterior. Pelo menos, ambos acreditavam nos Estados Unidos da Europa e encorajavam a sua concretização. Ambos difundiam pela escrita, afinal, uma ideia política. No caso de Adolfo Casais Monteiro a poesia seria a via privilegiada.

\footnotetext{
58 A este propósito é nossa intenção estudar esta figura relevante para a História da Unidade Europeia, sendo de destacar a sua obra Paneuropa, escrita em 1923 e que vale a pena ler pela sua ainda actualidade, ainda "sonho por realizar".

59 Carta da Legação de Portugal na Suiça, 28 de Setembro de 1948, MNE/AHD/2P/A50/M37.
} 
Europa seria o poema em português, também traduzido em inglês, a antecipar aquela que, justamente, se consideraria uma das línguas preferenciais da Europa Unida dos nossos dias.

Em 23 de Maio de 1945 foi, então, escutado o poema, lido aos microfones da B. B. C. de Londres, pela voz de António Pedro, um intelectual emigrado ${ }^{60}$. Estávamos no rescaldo da Segunda Grande Guerra, quando, quinze dias antes, se dera a vitória dos Aliados sobre o Eixo nazi-fascista. De certa forma, tinha sido a vitória da liberdade contra a opressão, da união livre dos povos contra uma união conseguida pela força. $\mathrm{O}$ poema português parecia, assim, vir celebrar a unidade europeia, tão sonhada pelos poetas, ideia tão difundida pelos intelectuais, mas, tão longe de ser uma realidade política. Tal como a "profecia" de Hugo, também, Adolfo Casais Monteiro parece querer antecipar o futuro:

\author{
"Europa, sonho futuro! \\ Europa, manhã por vir, \\ fronteiras sem cães de guarda, \\ nações com seu riso franco \\ abertas de par em par!
}

Europa sem misérias arrastando seus andrajos,

virás um dia? virá o dia

em que renasças purificada?

Serás um dia o lar comum dos que nasceram

no teu solo devastado?

Saberás renascer, Fénix, das cinzas

em que arda enfim, falsa grandeza,

a glória que teus povos se sonharam

\footnotetext{
60 É de referir que a obra em causa é dedicada, precisamente, a António Pedro, "que foi na hora própria a voz de todos os portugueses que não esqueceram a sua condição de europeus e cidadãos do mundo" (dedicatória). Como salienta José Augusto-França numa edição posterior desta obra, editada por ocasião da Europália 91, pela editora Nova Renascença, António Pedro realizou em Lisboa, em Novembro de 1940, juntamente com António Dacosta, uma exposição de pinturas de temática europeia, contrariando o nacionalismo característico da época e, muito particularmente, da temática nacionalista da Exposição do Mundo Português. Poeta, pintor e jornalista, António Pedro partiria para Londres, em Janeiro de 1944, onde seria contratado pela B. B. C. Aí seria o comentarista da secção portuguesa, sendo o representante de todos os europeus e cidadãos do mundo. No texto "In Memoriam", José Augusto-França lembra como no fim da guerra, regressando a Portugal, António Pedro seria preso pela polícia política, acusado de traição à pátria.
} 
- cada um para si te querendo toda?

Europa, sonho futuro,

se algum dia há-de ser!

Europa que não soubeste

ouvir do fundo dos tempos,

a voz na treva clamando

que tua grandeza não era

só do espírito seres pródiga

se do pão eras avara!

Tua grandeza a fizeram

os que nunca perguntaram

a raça por quem serviam.

Tua glória a ganharam

mãos que livres modelaram

teu corpo livre de algemas

num sonho sempre a alcançar!

Europa, ó mundo a criar!

Europa, ó sonho por vir

enquanto à terra não desçam

as vozes que já moldaram

tua figura ideal,

Europa, sonho incriado,

até ao dia em que desça

teu espírito sobre as águas!

Europa sem misérias arrastando seus andrajos,

virás um dia? virá o dia

em que renasças purificada?

Serás um dia o lar comum dos que nasceram

no teu solo devastado?

Renascerás, Fénix, das cinzas 
do teu corpo dividido?

Europa, tu virás só quando entre as nações

o ódio não tiver a última palavra,

ao ódio não guiar a mão avara,

à mão não der alento o cavo som de enterro

dos cofres digerindo o sangue do rebanho

- e do rebanho morto, enfim, à luz do dia,

o homem que sonhaste, Europa, seja vida!“61.

Este poema, lido em português, aos microfones da B. B. C. de Londres, antena preferida dos democratas, teria, por isso, uma grande repercussão: uma audiência máxima, se tivermos em conta que foi transmitido numa noite de rescaldo da Grande Guerra. E assim, "pela voz forte e timbrada de um intelectual então emigrado, António Pedro, esse poema da autoria de Adolfo Casais Monteiro, um dos nossos mais corajosos poetas resistentes à ditadura, acordou em quantos o escutavam a esperança de que também para Portugal a hora da liberdade iria soar, na nova Europa que se erguia sobre o sangue e os escombros decorrentes da criminosa aventura totalitária hitleriana"62.

Se por um lado se celebrava o fim da guerra e o advento de uma Nova Europa, temia-se, também, que este pacifismo não fosse duradouro. Muitos ódios continuavam vivos, embora contidos. Daí o tom eufórico e simultaneamente cauteloso do poema: "Europa, sonho futuro! /Europa, manhã por vir"63, mas, como todos os sonhos, vive da incerteza da sua realização: "virás um dia? virá o dia/ em que renasças purificada?"64. Se o poeta acredita numa Europa Unida, fundamentada numa história comum, falando, por isso, de uma casa comum europeia, expressão tão repetida na actualidade, por outro, a mesma história tem mostrado quanto os traços que a unem são motivos de constantes desuniões. Assim, essa Europa potencialmente una, só conseguirá cumprir o seu destino no dia em que ouvir e seguir a sua "alma". A Europa tem um espírito de unidade que não encontra, porém, correspondência na sua história sangrenta. O corpo europeu está, por isso, desligado do seu espírito, e a Europa está ferida pelos ódios que não respeitam

\footnotetext{
61 Adolfo Casais Monteiro, Europa, parte I, Lisboa, Editorial Confluência, 1946, pp. 13 a 15.

62 José Augusto Seabra, Prefácio à obra citada, p. 5.

63 Adolfo Casais Monteiro, op. cit., p. 13.

64 Idem, ibidem.
} 
a sua identidade. Mas há sempre a esperança de vir a recuperar a unidade, "quando entre as nações o ódio não tiver a última palavra",65, quando um Novo Homem fizer uma Nova Europa. Entretanto, a Europa vive de tratados de paz que não escondem, por isso, as tentações hegemónicas que levam às guerras. Adolfo Casais Monteiro disso tem disso consciência plena.

Mas à Europa de "Nações" e sem fronteiras, idealizada pelo poeta, sucederia, afinal, "uma Europa dividida em breve pela guerra fria, pela cortina de ferro, pelo muro de Berlim, com o totalitarismo estalinista e os campos de concentração soviéticos a Leste, onde inexoravelmente um império ideológico e armado calcaria sob a sua bota a independência e a liberdade dos povos a ele submetidos"66. Daí o alerta lançado por Adolfo Casais Monteiro pressentindo a eminência de novos conflitos, comum aos sobreviventes de guerra.

Este poema seria, também, um apelo à fraternidade dos Povos Unidos da Europa. Unidos pela liberdade, tão sonhada na resistência, e projectada para um dia ser vivida num regime político oposto ao totalitarismo, fascismo ou qualquer forma de autoritarismo, só numa sociedade democrática seria, enfim, possível uma verdadeira união de povos, esta última fundamentada nos valores da paz, da solidariedade e do respeito pelos Direitos Humanos. Estes deviam ser os verdadeiros valores defendidos pela política. Uma política fundada numa verdadeira vida na cidade que procura, assim, servir os seus cidadãos, independentemente dos partidos que os possam dividir; mais importante do que quaisquer querelas partidárias é a União dos Povos Unidos da Europa:

\footnotetext{
"Homens sem partido e de todos os partidos, que nasceram com a revolta porque não lhes vale de nada viver para ser escravos, homens sem partido e de todos os partidos — menos todos quantos só sabem dizer ORDEM! e reclamar VIOLÊNCIA! os que pedem sangue porque são sanguinários, sim, mas também todos os que nunca souberam querer nada, os que dizem Não é possível que se torturem os presos políticos
}

\footnotetext{
65 Idem, ibidem.

66 José Augusto Seabra, op. cit., p. 6.
} 
os que não podem acreditar

porque não querem ser incomodados pela pestilência dos

crimes cometidos para eles

- para eles continuarem a acreditar que a ORDEM não

é apenas mordaça

sobre as bocas livres que hão-de gritar até ao fim do mundo

QUE SÓ O HOMEM LIVRE É DIGNO DE SER HOMEM! ",67.

É de salientar que a Europa do Futuro, sugerida pelo poeta é, também, uma Europa aberta à universalidade e, daí a insistência da expressão "Europa, ó mundo a criar". Julgamos não trair o seu pensamento se, para além de uma Europa Unida, pensarmos um Mundo Unido e, assim, à maneira de Victor Hugo, os Estados Unidos da Europa seriam um primeiro passo de uns Estados Unidos do Mundo.

No século XXI, a Europa continua uma obra inacabada, um "sonho por realizar". Apesar dos sessenta anos de construção europeia, e das efectivas realizações conseguidas, o projecto europeu, anunciado logo a seguir à primeira guerra mundial, e concretizado pelo "método dos pequenos" passos após o segundo conflito, ainda mantém a sua actualidade. A Europa continua a ser a Europa, sonho futuro.

67 Idem, ibidem, quinta parte, pp. 35-38. 